DOI: $10.25178 /$ nit.2019.3.13

\title{
Модификация архетипического образа тувинского шамана в творчестве М. Б. Кенин-Лопсана
}

\author{
Зоя Б. Самдан
}

Тувинский институт гуманитарных и прикладных социально-экономических исследований при Правительстве Республики Тыва, Российская Федерация

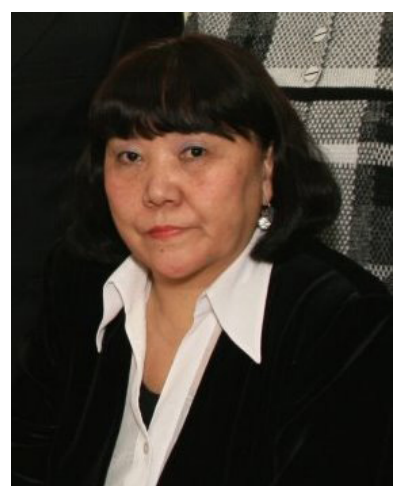

В статье представлен анализ модификации архетипического образа шамана в творчестве известного тувинского исследователя шаманизма и писателя М. Б. Кенин-Лопсана. Источниковой базой выступили его наиболее значительные произведения: поэма «Конеи шамана» (1971), романы «Исчезнувшая девушка» (2000) и «Судьба шаманки» (2016).

Образ шамана в творчестве М. Кенин-Лопсана претерпевал изменения в соответствии с историческими событиями в Туве ХХ века. Выделены два этапа эволюции творчества писателя: советский (1950-1990 г2.) и постсоветский (с 1991 г. - по настоящее время). Прототипом образа шамана стала бабушка писателя - шаманка Куулар Хандыжап, пережившая репрессии, аресты, тюремные заключения. Особенно ярко он представлен в романе «Судьба шаманки», где основная сюжетная канва строится на основе переплетения мифологического и исторического времени, загадочных метаморфоз шамана и его взаимодействия с другими персонажами. Если в поэме «Конеи шамана» шаман изображался автором как плут, то в романе «Исчезнувшая девушка» он стал жертвой, а в «Судьбе шаманки» - бориом за справедливость.

Многогранность деятельности М. Б. Кенин-Лопсана позволяет рассматривать его и как исследователя шаманизма - ученого, и как шамана-практика, и как хранителя шаманских традиций, и как художника, творчески осмысляюще$2 о$ судьбы тувинского шаманизма. Модифицированные образы шаманов, развитые в его литературном творчестве, оказались весьма востребованными как в Туве, так и за ее пределами.

Ключевые слова: Монгуш Борахович Кенин-Лопсан; Тува; тувинцы; тувинский шаманизм; шаман; шаманизм; литературный образ; тувинская литература; архетип; неотрадиционализм

\section{Для цитирования:}

Самдан 3. Б. Модификация архетипического образа тувинского шамана в творчестве М. Б. Кенин-Лопсана [Электронный ресурс] // Новые исследования Тувы. 2019, № 3. URL: https://nit.tuva.asia/nit/article/view/872 (дата обращения: дд.мм.гг.). DOI: $10.25178 /$ nit.2019.3.13

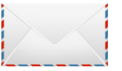

Самдан Зоя Баировна - кандидат филологических наук, старший научный сотрудник, ведущий научный сотрудник группы литературоведов Тувинского института гуманитарных и прикладных социально-экономических исследований при Правительстве Республики Тыва. Адрес: 667000, Россия, г. Кызыл, ул. Кочетова, д. 4. Тел.: +7 (394-22) 2-39-36. Эл. адрес: samdan-sn@yandex.ru

Samdan Zoya Bairovna, Candidate of Philology, Senior Research Fellow, Group of Literary Critics, Tuvan Institute for the Humanities and Applied Social and Economic Studies under the Cabinet of Ministers of the Republic of Tuva. Postal address: 4 Kochetov St., 667000 Kyzyl, Russian Federation. Tel.: +7 (39422) 2-39-36. E-mail: samdan-sn@yandex.ru 


\title{
Modifications of the archetypal image of the Tuvan shaman in the works of M. B. Kenin-Lopsan
}

\author{
Zoya B. Samdan \\ Tuvan Institute for Humanities and Applied Socioeconomic Studies \\ under the Cabinet of Ministers of the Republic of Tuva, Russian Federation
}

\begin{abstract}
The article analyses a modification of the archetypal image of shaman in the works of M. B. Kenin-Lopsan, the famous Tuvan scholar of Shamanism and writer. Our study covers his most significant works: a poem 'The End of the Shaman' (1971); novels 'The Girl Who Disappeared' (2000) and 'The Fate of a Shamaness' (2016).

The image of the shaman in the works of M. Kenin-Lopsan underwent transformation, as the historical events in Tuva were unfolding throughout the 20th century. The author's work can be categorized into the Soviet (1950-1990) and post-Soviet (from 1991) periods. A prototype for the image of the shaman was found in the writer's grandmother - the shamaness Kuular Khandizhap, who survived the repressions, arrests and several imprisonments. An exceptionally vivid portrayal of a shaman appears in the novel 'The Fate of the Shamaness' where the basic plot device is the symbiosis of mythological and historical time. Through her mysterious metamorphoses, the shamaness can interact with other characters. While in the poem 'The End of the Shaman' the shaman acted as a trickster, in the novel 'The Girl Who Disappeared' he becomes a victim, and in the novel 'The Fate of Shamaness' he evolves into a fighter for justice.

The diversity of the M. B. Kenin-Lopsan's work allows us to see him as a scholar of Shamanism, a practicing shaman, a keeper of Tuvan shamanic traditions and as an artist who gives them a creative twist. The interpretations of shamans he offered in his literary work became very popular both in Tuva and abroad.
\end{abstract}

Keywords: Mongush Borakhovich Kenin-Lopsan; Tuva; Tuvans; Tuvan Shamanism; shaman; Shamanism; literary image; Tuvan literature; archetype; neotraditionalism

For citation:

Samdan Z. B. Modifications of the archetypal image of the Tuvan shaman in the works of M. B. Kenin-Lopsan. The New Research of Tuva. 2019, № 2 [online] Available at: https://nit.tuva.asia/nit/article/view/872 (access date ...). DOI: 10.25178/nit.2019.3.13

\section{Введение}

Исследование проблем сохранения культурного наследия народов Тувы в условиях глобализации и информатизации современного мира вызывает интерес у ученых-гуманитариев, в том числе в связи со сложившимися объективными процессами архаизации трансформирующихся обществ. Приверженность современного тувинского общества традиционализму, обращение в переломные периоды истории к традиционным ценностям духовной этнической культуры, свидетельствуют о стойкости национальных традиций и непрерывности исторической памяти тувинского этноса. Преемственность традиций духовной культуры, процесс их постепенной трансформации в условиях современности можно обнаружить через аутентичные тексты и произведения искусства. Поэтому исследование процесса модификации фольклорно-мифологических архетипических образов в произведениях современной тувинской литературы, определение их роли в сохранении глубинных пластов самобытной тувинской культуры, приобретает особую актуальность.

Понятие «архетип», по обобщающему определению А. А. Фаустова, «понимается как “осадок памяти” всего того регулярно повторяющегося, что было пережито архаическим человечеством и что отдельно взятому человеку передается “генетически”... Архетипические образы и мотивы - это “вариации на тему A”, наиболее интенсивно проявляются в мифах, сновидениях, религиозных и алхимических учениях, в художественном / литературном творчестве, в пограничных и кризисных состояниях субъекта и т. д.» (Фаустов, 2008: 24).

Под понятием модификация архетипических образов в произведениях литературы имеется в виду процесс художественного видоизменения фольклорно-мифологических образов-архетипов в индивидуальном творчестве, их интерпретация, переосмысление писателем и придание им новых смыслов, новых содержаний, новых форм. 
Обращение к традициям, особенно в сфере индивидуального творчества, имеет цель не просто восстановление старых ценностей, а его творческое использование в новых условиях. Для раскрытия проблемы модификации архетипических образов важны теоретические работы о процессах традиционализма и неотрадиционализма, разработанные исследователями социальной философии А. Б. Гофманом, Ч. К. Ламажаа, Ю. В. Попковым, С. А. Мадюковой и др. (Гофман, 2008; Ламажаa, 2013; Мадюкова, Попков, 2010). В частности, особый интерес для нас представляет характеристика неотрадиционализма, предложенная Ч. К. Ламажаа по отношению к трансформирующимся обществам. Она полагает, что теория неотрадиционализма направлена на возрождение традиций: и для адаптации общества в современных условиях, и для его эффективного развития, т. е. практически для его модернизации на основе логики собственной культуры (Ламажаa, 2010: Электр. ресурс). В методологическом плане мы опираемся также на определения неотрадиционализма, сформулированные представителями новосибирской этносоциологической школы С А. Мадюковой и Ю. В. Попковым: «Неотрадиционализм - как осознанная реакция - это феномен не традиционного, а модернизирующегося переходного общества (Мадюкова, Попков, 2010: 105).

Процессы неотрадиционализма, характеризующиеся как наиболее перспективный путь сохранения культурного наследия тувинского народа на современном этапе, выраженный через модификацию архетипических образов в сфере индивидуального творчества, можно продемонстрировать на примере многогранной подвижнической деятельности писателя, ученого, краеведа Монгуша Бораховича КенинЛопсана. В его творчестве, на наш взгляд, наиболее последовательно и достоверно отразилась идея сохранения культурного наследия и исторической памяти тувинского этноса. Эта идея воплотилась в жизнь через органическое переплетение его научной и писательской деятельности. Художественные образы в его творчестве, созданные на основе фольклорно-мифологических архетипических образов, видоизменялись под влиянием разных факторов исторического развития тувинского общества и индивидуальных особенностей его творческой личности.

Цель данной статьи - анализ проблемы модификации архетипического образа шамана в творчестве М.Б. Кенин-Лопсана. Источниковой базой для данного исследования выступили его наиболее значительные произведения, отражающие динамику осмысления образа шамана. Модификацию образа шамана мы будем анализировать на основе его поэмы «Конец шамана» (1971), романов «Исчезнувшая девушка» (2000), «Судьба шаманки» (2016). В таком ракурсе творчество М. Б. Кенин-Лопсана рассматривается впервые. Анализ мы выстроим с помощью сравнительно-исторического и герменевтического методов исследования.

Мы опираемся также на его научные труды по шаманизму и обширный круг литературы историков и этнографов, фольклористов и литературоведов, культурологов и искусствоведов. Наиболее основательные работы о нем и его творчестве написали Р. Ф. Итс, М. А. Дэвлет и др. (Итс, 1966; Дэвлет, 2009). Мы также анализировали его творчество ранее (Самдан, 2001).

\section{Эволюция творчества М. Б. Кенин-Лопсана}

Идея сохранения исторической памяти культурного наследия тувинского народа наиболее последовательно и ярко отразилась в творчестве М. Б. Кенин-Лопсана через образ шамана. И это естественно. Его человеческая и творческая судьба складывалась под влиянием объективных исторических факторов тувинской действительности, обусловленных кардинальными переменами в жизни тувинского общества XX века и перипетиями его личной биографии.

М. Б. Кенин-Лопсан родился 10 апреля 1925 г. на берегу реки Хондергей, в местности Чаш-Тал ДзунХемчикского хошуна Тувинской Народной Республики.

Он рос в традиционной многодетной семье охотника, в окружении прекрасных знатоков тувинского фольклора. Является выходцем из шаманского рода сат (по материнской линии).

В его воспитании огромную роль сыграли бабушка-шаманка Куулар Хандыжап и исследователь древностей, ученый-тюрколог С. Е. Малов. Увлеченность темой шаманизма предопределила всю его дальнейшую жизнь.

Изучение шаманов, шаманизма и изменение образов шаманов в творчестве М. Б. Кенин-Лопсана претерпевало изменения. Чтобы понять почему писатель периодически обращался к образу шамана и каким образом интерпретировал, переосмысливал и видоизменял его в своем творчестве, необходимо отследить этот процесс в контексте основных направлений и этапов его писательской, научной и практической деятельности. 
Литературную и научную деятельность М. Б. Кенин-Лопсана мы разделяем на два больших этапа: советский (1950-1990 гг.) и постсоветский (с 1991 г. - по настоящее время). При анализе художественного и научного осмысления образа шамана им в постсоветское время мы опираемся на периодизацию процесса возрождения национальной культуры Тувы с социокультурной точки зрения, которую предлагает М. М.-Б. Харунова (Харунова, 2010: Электр. ресурс). Она выделяет три периода: конец 1980-х годов, когда происходило освобождение от советской системы регулирования этнической культуры; 2) начало 1990-х годов - признание некоторых культурных традиций на уровне власти региона, предоставление им официального статуса; 3) с середины 1990-х годов и до сегодняшнего дня - активное развитие традиций национальной культуры во всех сферах культуры, при поддержке власти Республики Тыва (там же).

Выпускник восточного факультета Ленинградского университета (1947-1952 гг.) М. Б. Кенин-Лопсан в советский период утвердился больше как писатель. В его творчестве выразились история быта, нравов, обычаев тувинцев, их психология и душа. Как поэт, публицист и прозаик он составил своеобразную художественную

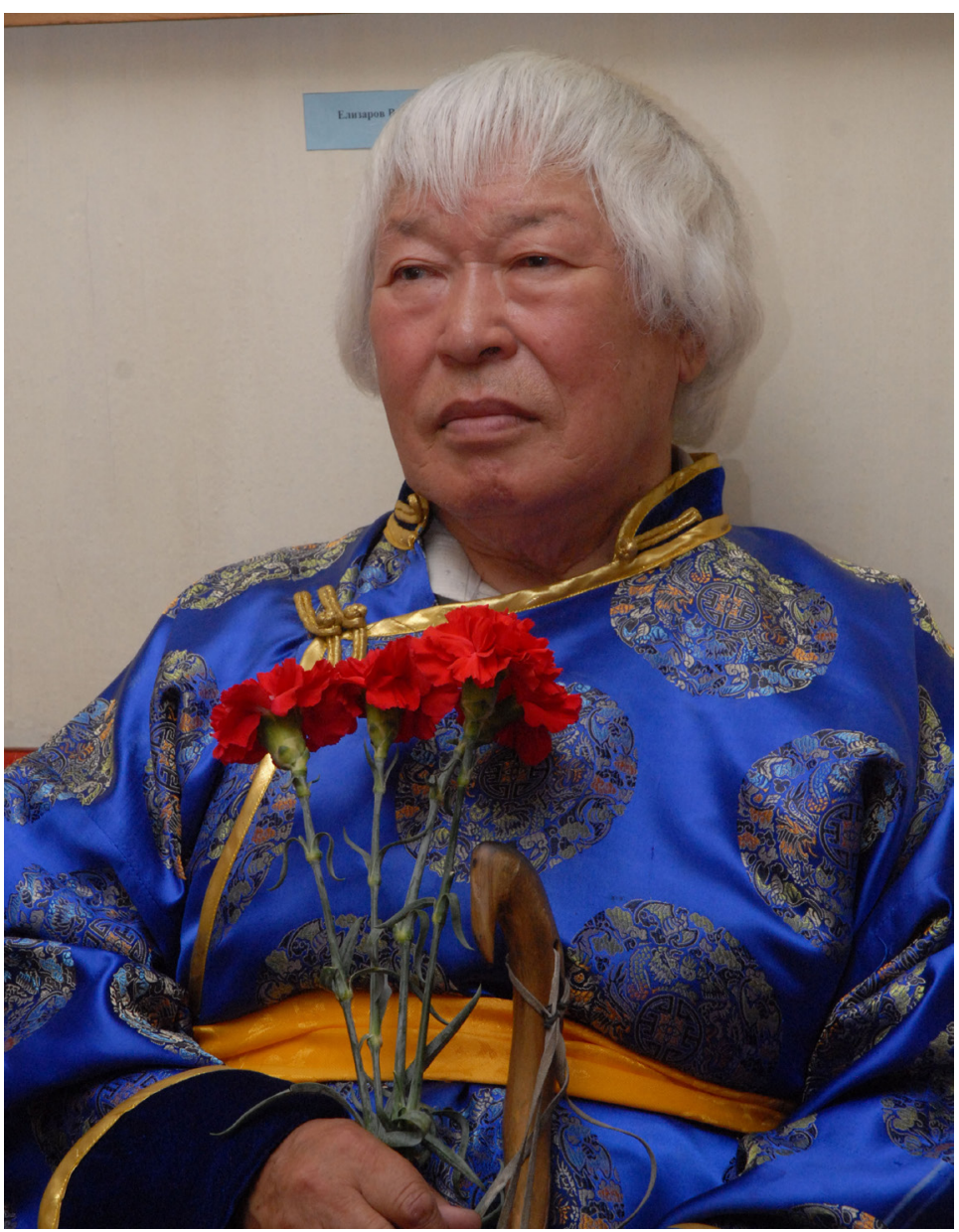

Фото 1. Монгуш Кенин-Лопсан. Фото Владимира Савиных Photo 1. Mongush Kenin-Lopsan. Photo by Vladimir Savinykh. летопись жизни тувинского народа. Он автор более двух десятков сборников поэзии и прозы (Кенин-Лопсан, 1975). В них тувинская архаика раскрывается в тесном переплетении фольклорно-мифологических образов с образами исторических персонажей.

Особое место в его творчестве занимают произведения на тему шаманизма и о судьбе людей, пострадавших в годы репрессий в Туве - в 1930-1950-е годы. В условиях идеологического запрета на изучение «пережитков прошлого» М. Б. Кенин-Лопсан тайно и систематически собирал тексты шаманского фольклора.

На первом этапе писательской и научной деятельности М. Б. Кенин-Лопсана было немало препятствий. В череде многих повседневных преград (отказ в работе в научном институте, отказ в выезде за границу, молчаливое игнорирование...), пожалуй, две все же оставили глубокий след в его сердце.Первая, когда в течение десяти лет, с 1955 по 1965 гг., ему задерживали выход его первого романа «Стремнина Великой реки», до 2005 г. не признавали его приоритет как автора первого тувинского романа (Самдан, 2015: 342-343). Вторая, когда его исследование тувинского шаманства вплоть до 1982 г. встречало упорное сопротивление со стороны партийных властей, расценивалось как пропаганда пережиточной религиозной идеологии (Самдан, 2003: 22-23; Дэвлет, 2009: 15).

Освободившись от партийной опалы, он защитил кандидатскую диссертацию по историческим наукам по теме «Сюжеты и поэтика тувинского шаманства» в 1982 г. в г. Ленинграде, Музее антропологии и этнографии им. Петра Великого под научным руководством д. и. н., проф. Д. Г. Савинова (Кенин-Лопсан, 1982). Позже он опубликовал монографию «Обрядовая практика и фольклор тувинского шаманства: конец XIX нач. XX в.» (Кенин-Лопсан, 1987).

\footnotetext{
${ }^{1}$ Фотография любезно предоставлена дочерью М. Б. Кенин-Лопсана - М. М. Кенин-Лопсан.
} 
На следующем этапе творчества М. Б. Кенин-Лопсана в судьбе писателя произошли кардинальные изменения. В начале 1990-х годов в Туве было разрешено проведение I Международного семинара шаманов и шамановедов (1993 г.), открылся Научный центр по изучению шаманизма при Тувинском краеведческом музее (1993 г.), создано общество тувинских шаманов «Дүңгүр», президентом которого стал М.Б. Кенин-Лопсан (1993 г.) и т.д. Его научная деятельность получила официальный статус. На этом этапе М. Кенин-Лопсан получил «второе дыхание», он открылся больше как ученый. Научные направления его деятельности также многогранны: фольклористика, история, этнография, шамановедение, этнопедагогика, мифология, искусствоведение и т. д. Начиная с 1944 г. и в течение всей жизни он систематически собирал материалы по тувинскому шаманству. За это время он работал с несколькими сотнями информантами, опубликовал тексты и исследования по шаманизму: «Тувинские алгыши» (на тувинском языке: Кенин-Лопсан, 1992; на русском языке Кенин-Лопсан, 1995), «Магия тувинских шаманов» (Кенин-Лопсан, 1993) и др.

С середины 1990-х годов научная и писательская деятельность М. Б. Кенин-Лопсана получает наиболее активное развитие. В 1997 г. в Санкт-Петербурге, в Музее антропологии и этнографии им. Петра Великого (Кунсткамера), под научным руководством д. и. н., проф. Д. Г. Савинова он защитил докторскую диссертацию по теме «Проблемы этнографического изучения тувинского шаманизма. По материалам шаманского фольклора» (Кенин-Лопсан, 1996). Под его руководством и участием был проведен II Международный симпозиум по изучению шаманизма (2003 г.), он опубликовал «Мифы тувинских шаманов» (Кенин-Лопсан, 2002), «Дыхание Черного Неба» (Кенин-Лопсан, 2010) и др.

В этот период он написал и издал три романа, два из которых мы рассмотрим.

Как показывает наш обзор, обращение М. Б. Кенин-Лопсана к теме шаманизма как к глубинной памяти этноса было постоянным. На начальном этапе обращение автора к образу шамана проходило трудный период преодоления запретительных установок, взгляды его не были окончательно сформированы и сформулированы. На постсоветском этапе его деятельности обращение к прошлому постепенно приобретает глубоко осознанное творческое развитие. Научное и художественное осмысление образа шамана идет параллельно. Этот взаимообусловленный процесс переосмысления и модификация этого образа мы можем увидеть на примере художественных произведений М. Кенин-Лопсана, написанных в разные периоды его творчества.

\section{Интерпретация образа шамана в поэме «Конец иамана»}

Несмотря на тот факт, что элементы шаманского фольклора присутствовали в художественных произведениях М. Кенин-Лопсана, шаманская тема в советское время была запрещенной. Тем не менее в 1966 г., когда писатель начал работать в краеведческом музее, он приступает к написанию отдельного произведения о шамане в лиро-эпическом жанре. Однако поэма «Конец шамана» была завершена им лишь спустя 5 лет - только в 1971 г., а издана годом позже (Кенин-Лопсан, 1972). Возможно, написание произведения на запретную тему потребовало определенного времени и соответствия идеологическим установкам. В творчестве М. Кенин-Лопсана скорее шла внутренняя борьба между естественным традиционным миропониманием писателя и вынужденным осуждением отсталых религиозных взглядов.

Основную сюжетную линию поэмы «Конец шамана» составляет пафос обличения хитрых манипуляций шамана Халака его секундантом Агыраром. Действие поэмы происходит в дореволюционное время и в годы установления народной власти в Туве.

«Красный вихрь Октября», то есть революционные события 1917 г., разрешает интригу между шаманом и сыном богача Аспандаем («И вот теперь я революцией гоним / и прокаженного изведал судьбину», «С тех пор, как красный вихрь всю землю раскачал, / я потерял предвидения двойную силу», «Народа суд конфисковал его стада / и отдал беднякам на радость всем аалам») (Кенин-Лопсан, 1972: $122,125)$.

Агырар разоблачает обман шамана Халака, они прячут шаманскую атрибутику в пещере. Спустя годы, после пожара, Агырар, от имени которого ведется повествование, находит тот клад и сдает его в музей.

В поэме бросается в глаза читателя противоречивость образа шамана, выражаемая в сюжетной канве произведения двойным тайным смыслом. Лирический герой как бы передает этот тайный смысл словами: «Я врал, что видел то, чего и не видел, / я говорил - не вижу, если даже видел» (там же: 25). 
Исследователь тувинской литературы В.С. Салчак верно отметил, что в завуалированном образе шамана скрыта главная мысль о притеснениях шаманов в годы тоталитаризма; также он объясняет идею произведения как предостережение от шаманов-шарлатанов, которые дискредитируют авторитет истинных благородных служителей культа (Салчак, 2015: 39). Правда, В. С. Салчак при этом не анализировал действия героев поэмы, характеризующие истинную суть тувинского шаманизма. Постараемся дополнить этот пробел.

Интерпретируя образ шамана в поэме «Конец шамана», М. Кенин-Лопсан, на наш взгляд, заложил в этом произведении основные характеристики аутентичного образа шамана. Раскрывая образ центрального героя - шамана Халака - писатель приводит убедительную характеристику способа получения шаманского дара шаманом небесного происхождения:

«Был однажды летом на охоте он -

Гром гремел и дождь хлестал со всех сторон.

И вдруг молнии копье, сверкнув во мгле,

Смаху пригвоздило юношу к земле...

Раз сражен он не был пулею небес -

Не сразит теперь ни бог, ни бес

Всех земных шаманов будет он сильней» (Кенин-Лопсан, 1972: 112).

Еще в экспозиции произведения автор выделяет образ шамана небесного происхождения от шаманов других категорий: шаманы, происходящие от шаманов-предков; от духов земли и воды; от злых духов «албыса»; от злых духов «аза (там же: 111).

Надо отметить, что пять категорий тувинских шаманов, отличающихся своим происхождением, М. Кенин-Лопсан исследовал в научной статье (Кенин-Лопсан, 1977). Впоследствии эти категории войдут в структуру его произведений как сюжетообразующие основы в создании образов шаманов разного происхождения.

М.Б. Кенин-Лопсан в поэме также художественно изображает мистические способы воздействия шаманов на страждущих: как призывать дождь, как достать табак с неба, как пустить пулю в грудь и т. д. (Кенин-Лопсан, 1972: 112, 116, 117).

Жанр поэмы позволяет М. Б. Кенин-Лопсану творчески использовать традиционные приемы повторов, поэтика которых близка к анафоре ${ }^{1}$, характерной для стихотворного построения шаманских призываний:

«...Агарой!

Нужна вода,

Небесный вождь,

Пошли сюда

Скорее дождь...» (там же: 115).

Для характеристики героев писатель также обращается к таким приемам фольклорной поэтики, как использование жанров моления, молитв, благопожеланий, пословиц («Конь от раны станет иноходцем, / человек от бедности - шаманом»; «Каждый своего себе отыщет черта» и т. д.); говорящих имен и прозвищ (Халак - межд. 'Увы!'; Агырар - 'сопровождать шамана, подражая его выражениям'; Аспандай (Аспан) - 'пузатая кобылка’ и т. д.).

Разумеется, в те годы, когда М. Кенин-Лопсан писал свою поэму, он еще не мог знать о предстоящих переменах в социальном строе общества, об изменении отношения к религии, в частности, шаманизму. Внутренние сомнения и борения по отношению к смене старых духовных ценностей новыми, происходящие в то время в сознании писателя, так или иначе отразились в его художественном творчестве как констатация факта о неизбежной утрате шаманских традиций. Тем не менее устойчивость традиционного мировоззрения, непоколебимая вера в духовные идеалы предков в сознании КенинЛопсана-писателя, подкрепляемая научными изысканиями Кенин-Лопсана-ученого, позволили ему найти оптимальную форму интерпретации образа шамана в советский период.

\footnotetext{
${ }^{1}$ Анафора (греч. anaphora, букв. - вынесение) - повтор слова или группы слов в начале нескольких стихов, строф, колонов или фраз (Гаспаров, 1987: 24).
} 
В идейном содержании поэмы образ шамана интерпретирован в духе советского времени. Традиционная поэтика подверглась изменениям под влиянием эстетики соцреализма: противопоставление образов бедняков и богачей, разоблачение «пережитков» старого времени, воспевание новой жизни. На этом фоне писателю все же удалось зафиксировать некоторые подлинные характеристики шамана небесного происхождения; поэтически изобразить шаманскую атрибутику, обряды и способы шаманского камлания. М. Кенин-Лопсан в своей одержимости темой шаманизма стремится преодолеть идеологические препоны. Его интерес к архаике продолжает внутренне подталкивать его к поиску новых форм в раскрытии образа шамана.

\section{Переосмысление образа иамана в романе «Исчезнувиая девушка»}

В течение нескольких десятилетий у М. Б. Кенин-Лопсана вызревал, по свидетельству самого автора, замысел написания широкого полотна о трагической судьбе тувинских шаманов в годы репрессий. И вот, после кардинальных перемен, произошедших в постсоветский период истории тувинского общества, за относительно короткий срок, друг за другом вышли три его романа: «Буян-Бадыргы» (Кенин-Лопсан, 2000a); «Исчезнувшая девушка» (Кенин-Лопсан, 2000b); «Судьба шаманки» (КенинЛопсан, 2016; который был написан еще в 2003 г.). Решающим мотивом для написания двух последних романов, на наш взгляд, стало давнее желание писателя воссоздать в художественных образах жизнь и судьбу людей, пострадавших в годы репрессий. В центре всегда стояла постоянно мучившая его много лет судьба бабушки-шаманки Куулар Хандыжап. Образ шаманки небесного происхождения в разных ипостасях вырисовывается в сюжете этих романов.

Роман «Исчезнувшая девушка» писался в три этапа: в 1963, 1989 и 1999 гг. Главная героиня романа Хертек Агана олицетворяет собирательный образ так называемых детей «врагов народа», незаслуженно пострадавших в годы репрессий. Сюжет романа строится вокруг мытарств девочки-сироты, переносящей невыносимые лишения в 1930-1950-е годы в поисках справедливой жизни в своем родном селении у подножия высокой горы Монгун-Тайга. Испытав все несправедливости тоталитарного режима, она в конце концов уходит под купол Вечного Синего Неба и находит свой вечный покой - умирает высоко в горах, в ледяной «юрте», под защитой духа-хозяина МонгунТайги.

Истории трагических судеб тувинских шаманов в композиции романа воссозданы через воспоминания, сновидения и внутренние монологи. Образ Куулар Хандыжап в одном эпизоде романа - во сне главной героини Аганы - изображается как реалистический образ. Шаманка рассказывает ей об истории своих лишений, как была трижды осуждена: в первый раз арестовали ее в 1929 г. за шаманское происхождение, освободили в 1941 г.; во второй раз осудили в 1938 г. за сокрытие врага народа, ее сына Куулара Сунгар-оола ${ }^{1}$; в третий раз посадили в тюрьму в 1948 г., осудив ее, 63-летнюю мать девяти детей на пятнадцать лет за лжеврачевание и осквернение профессии советских врачей.

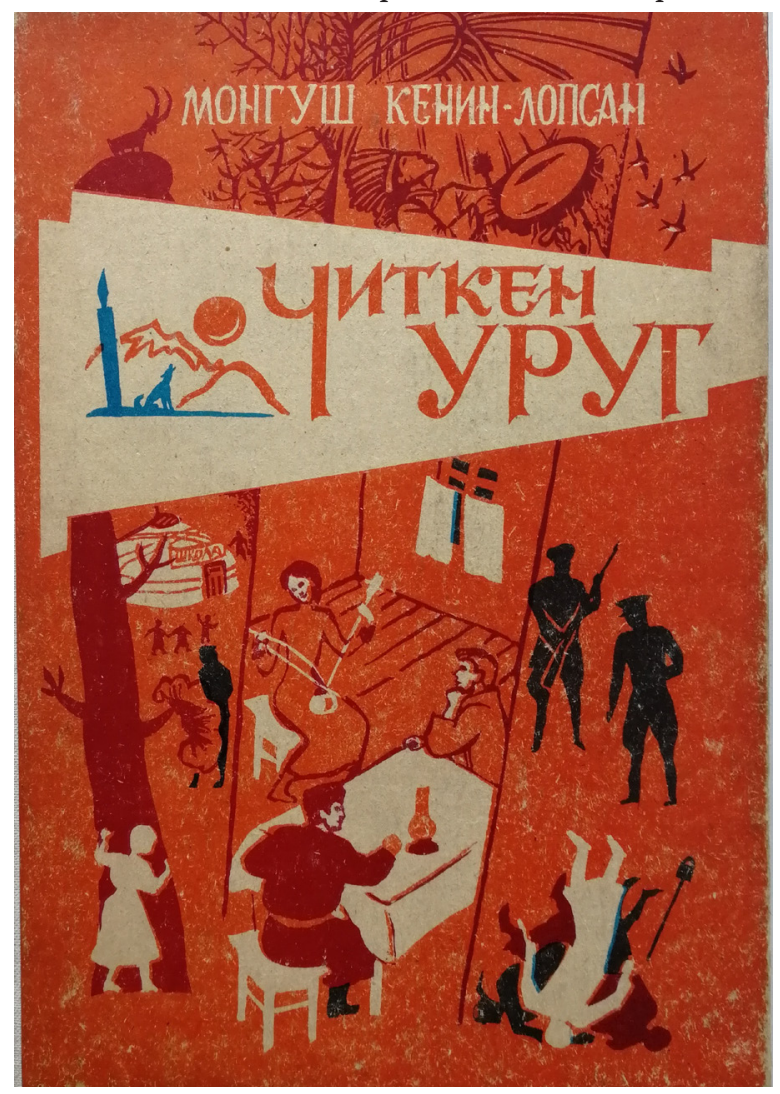

Фото 2. Обложка книги М. Кенин-Лопсана

«Читкен уруг» («Исчезнувшая девушка») 2000 г. Photo 2. Cover of M. Kenin-Lopsan's book "Chitken urug” (“The girl who disappeared”) 2000.

${ }^{1}$ Куулар Товунак оглу Сунгар-оол родился в 1908 г. в сумоне Солчур Овюрского хошуна; работал послом Тувинской Народной Республики в Монгольской Народной Республике, до ареста был студентом Коммунистического университета трудящихся Востока (КУТВа) в г. Москве. Член Правительства ТНР, ложно обвиненный за участие в контрреволюционной организации. Был расстрелян 16 октября 1938 года в числе 7 руководителей ТНР. Реабилитирован в 1964 г. 
Сон девушки о ее встрече с шаманкой передает основную идею произведения о неразрывности связи времен, о преемственности в жизни рода, о сохранении памяти. Наказы шаманки-провидицы и ее уверенность в неизбежности прихода лучших времен, ее вера в то, что зло будет наказано, а добро восторжествует, придает финалу романа оптимистическое звучание и логическую завершенность.

Главной опорой героини в поисках защиты от несправедливой жизни становится ее вера в силу Вечного Синего Неба, вера в заступничество духов-хозяев Монгун-Тайги. Эта вера в сверхъестественные силы природы является основой шаманского мировоззрения. Поэтому сюжетные линии о шаманах, в центре которых стоит образ шаманки небесного происхождения, органически переплетается с главной сюжетной линией о девушке-сироте. Трагическая история дочери «врага народа» в романе показана не просто как исповедь жертвы социальной несправедливости, а скорее как противостояние человека с несломленным духом, которому помогают оставаться человеком незыблемые нравственные законы предков.

Одним из основных источников художественно-изобразительных средств в романе является тувинская мифология. В создании художественных образов, в построении сюжетных линий и композиции произведения писатель использовал художественный прием мифологизма. Мифологизм романа «Исчезнувшая девушка» впервые рассмотрела исследователь исторической поэтики тувинской литературы У. А. Донгак (Донгак, 2007). Она аргументированно проанализировала роль мифологемы Синего Неба, характеризующую основное идейное содержание романа в целом (там же: 70). Подтверждая ее тезисы о мифологизме романа, мы бы хотели рассмотреть приемы использования писателем тувинской шаманской мифологии в художественном осмыслении образа шамана.

Глава, воссоздающая галерею портретов шаманов, живших в Моген-Бурене, состоит из нескольких разделов, которые отличаются стройной композицией: сначала приводится биография каждого шамана по-отдельности - Амыр-Биди, Иргит Содуна, Хертек Ундун, Седип, Мандырга, Иргит Конгар по прозвищу Улуг-Хам или Холурааш; история его шаманской родословной в соответствии с определенной категорией, детально описывается его шаманская атрибутика, совершаемые им обряды и способы камлания, а затем приводится миф, связанный с историей происхождения шамана. (Кенин-Лопсан, 2000b: 82-94). Использование такой композиции, особенно включение мифа, придает сюжету романа новый смысл. Штрихи такой композиции впервые появлялись в поэме «Конец шамана». Однако идеологические установки и стихотворная форма не позволяли воплотить замысел полностью. В крупном повествовательном жанре романа этот прием позволил М.Б. Кенин-Лопсану выстроить стройную композицию в полной форме, что дало возможность раскрыть специфические особенности тувинского шаманизма. Пожалуй, применение такой композиции способствовало видоизменению образа шамана в творчестве писателя. К сожалению, не все истории шаманов Моген-Бурена получили дальнейшее развитие в сюжете романа.

Прием поэтических повторов-лейтимотивов в прозаическом произведении применяется своеобразно - автор часто использует в начале каждого раздела повторы одного ключевого слова, постепенно как бы лесенкой выстроив «ограду» и акцентируя этим основную мысль данного синтаксического оборота. М. Б. Кенин-Лопсан в романе также, как в поэме продолжает применять фольклорную поэтику. Так, например, нарекает своих персонажей говорящими именами и прозвищами - Чылан-Карак (Змеиные глаза), Чес-Хаай (Медный нос), Мангыс-Суугу (Печка Чудовище), Өшкү (Козлиха), Аскак-Контр (Хромой Контр) и т. д.

Так, идейное содержание романа, воплощенное в образах шаманов, на этот раз было освобождено от идеологических установок М. Кенин-Лопсаном. Писатель не осмеивает, не разоблачает, не осуждает шаманов как в содержании поэмы «Конец шаманка», а с беспощадной откровенностью изображает правду о трагических страницах истории репрессий в Туве. Он воссоздал в художественных образах типичные истории жизни репрессированных шаманов. Такая судьба постигла в те годы многих служителей культа почти по всей Туве.

Изменилась структура образа шамана в романе «Исчезнувшая девушка», в него вкладываются новые смыслы. Образ и идея, как полагает У. Донгак, в рамках поэтики художественной модальности здесь приобретает автономный статус. На основе традиционалистской и мифопоэтической конструкции мира создается качественно иной художественный мир (Донгак, 2017: 151). Писатель выразил свое личностное понимание, философски осмыслил исторические события в жанре реалистического романа. Формы применения фольклорной поэтики в романе усложняются, мифологизм романа углубляет его идейное содержание. 


\section{Модификация архетипического образа иамана в романе «Судьба иаманки»}

Венцом многолетней исследовательской и творческой работы М. Б. Кенин-Лопсана над образом шамана стал выход на свет в 2016 г. его романа «Судьба шаманки» (Кенин-Лопсан, 2016), жанровую разновидность которого мы определили как роман-миф. К этому сложнейшему жанру романа в тувинской литературе М. Кенин-Лопсан обратился впервые, что характеризует глубину художественного проникновения писателя в этот архетипический образ.

Мифологизм в романе «Судьба шаманки» как характерное явление, как художественный прием в творчестве М. Кенин-Лопсана, передает мироощущение носителя культуры, ученого, писателя. Это роман-миф, поскольку отражает мифологические традиции тувинцев, о которых писал Е. М. Мелетинский: они являются «живой подпочвой национального сознания и даже многократное повторение тех же мифологических мотивов символизирует в первую очередь стойкость национальных традиций, национальной жизненной модели» (Мелетинский, 2006: 298). Художественное творчество М. Б. КенинЛопсана позволило жанру романа, пластичность которого отмечалась М. М. Бахтиным (Бахтин, 1988), трансформироваться и погрузиться в мифологические глубины. В романе «Судьба шаманки» основная сюжетная канва строится на основе переплетения мифологического и исторического времени и загадочных метаморфоз образа шамана и других персонажей. Души умерших шаманов путешествуют по земле и космосу. Композиция выстроена так, что категории шаманов разного происхождения составляют стройную систему сюжетных линий. Поэтика романа-мифа усложнилась - изображение мира потустороннего, трансцендентального превалирует над реалистическим миром, миром людей.

Сквозной образ шамана небесного происхождения развивался в творчестве М. Кенин-Лопсана постепенно - начиная от поэмы «Конец шаман», романа «Исчезнувшая девушка», до центральной фигуры романа «Судьба шаманки». Прототипом этого образа, как мы уже отмечали, является бабушка писателя Куулар Хандыжап, ее жизнь и судьба, полная драматизма и трагизма. В данном романе она появляется в образе Белой Волчицы. С помощью приема диалога с другими мифологическими персонажами - с Донгаком Кайгалом, Желтым

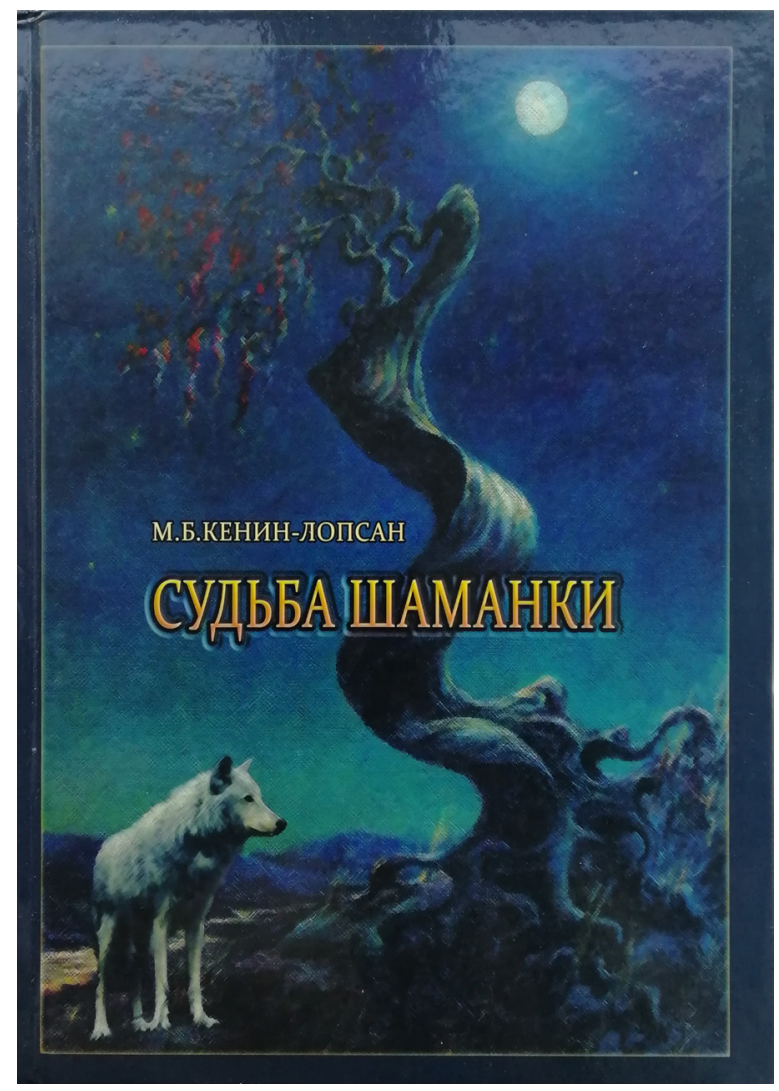

Фото 3. Обложка книги М. Кенин-Лопсана «Судьба шаманки» 2016 г.

Photo 3. Cover of M. Kenin-Lopsan's book

"The Fate of the shaman" 2016.
Чертом, Бубном и т. д. - она ведет повествование о судьбе шаманов разного происхождения.

Способ получения шаманского дара шаманами небесного происхождения в романе излагается устами самой Куулар Хандыжап: «Однажды я пасла стада овец и коз... И вдруг на чистом небе появилась черная тучка. Пошел град. Я стала жертвой молнии. Когда я пришла в сознание, надо мной гремел бубен старого шамана. Он был очень уважаемым и очень знаменитым шаманом. Он благословил меня в путь небесного шамана. Итак, я стала шаманом небесного происхождения, так как мои предки были шаманами небесного происхождения...» (Кенин-Лопсан, 2016: 85). Самая драматичная сюжетная линия - повествование Белой Волчицы о своей земной жизни. Мифологическая канва ее рассказа путешествие Души шаманки Хандыжап в Космосе и на земле - время от времени возвращает сюжет романа к реальной жизни, в историческом ракурсе времен жестоких репрессий, происходящих в Туве в 1930-1950-е гг.

В кульминации романа открываются драматические страницы жизни шаманки Хандыжап, воссозданные из документальных архивных источников. Трижды осужденная и отбывшая долгий срок заключения в сталинских лагерях шаманка Куулар Хандыжап, освободившись из тюрьмы, возвращается в Туву. Но не добравшись до родной юрты, умирает в пути. Свою трагическую судьбу она излагает устами Белой Волчицы, олицетворяющей её Душу. 
Сквозная сюжетная линия, связанная с образом шаманки небесного происхождения, выстроена в тесном взаимодействии с мифологическими образами других шаманов, зверей, животных, птиц, среди которых выделяются образы медведя и волка. В романе мифологические образы и мотивы, связанные с медведем и волком, перевоплощенные в их ожившие Души, постоянно сопровождают образ шаманки. И это не случайно. В практике тувинского шаманства они выполняют функции главных шаманских помощников-идолов, так как их происхождение связано с историей происхождения предков тувинского этноса, отдельных их родов и шаманов определенной категории. Эти религиозно-мифологические представления зафиксированы в тувинских шаманских мифах и шаманских алгышах, которые были собраны, классифицированы, исследованы и опубликованы М. Б. Кенин-Лопсаном в его работах (КенинЛопсан, 2002, 2007, 2010: 64-70, 99-104). Фольклорные тексты, переосмысленные и интерпретированные писателем в соответствии с отдельными сюжетными линиями романа, включены в его художественную ткань в разных вариантах.

В романе «Судьба шаманки» мифологизм стал инструментом структурирования повествования. Кенин-Лопсан широко используеттакие элементарные проявления структурности как простые повторения, которым придавалась внутренняя значимость с помощью техники лейтмотивов (Мелетинский, 2006: 296). Этот прием, заложенный писателем в предыдущих его произведениях, в романе «Судьба шаманки» еще более развит. Определенные композиционные части романа М. Кенин-Лопсана начинаются и заканчиваются с простых повторений-лейтмотивов:

«Спокойно светит полная Луна.

Мудрый Бубен думает.

Желтый Черт дремлет» (Кенин-Лопсан, 2016: 124).

Трансформация образа шамана в творчестве М. Кенин-Лопсана удивительно парадоксальна и в то же время исторически обусловлена. Живой, реалистический, типичный образ шамана, взятый из тувинской действительности, выстраданный самим писателем, художественно переосмысливается и становится в его романе поэтическим, мистическим, героическим образом неистового борца за справедливость. Так, например, свой гнев и несогласие с несправедливостью она выражает в своей обличительной речи, обращенной к Душе шамана Кайгала: «Моя совесть чиста перед моим тувинским народом... Да, я была шаманкой небесного происхождения. Клянусь совестью, что я никогда не была японской шпионкой. Я никогда не скрывала в лесах и горах врагов моего народа... Я хочу, чтобы у моих детей была счастливая судьба...» (Кенин-Лопсан, 2016: 91).

Таким образом, образ шамана видоизменился: если в поэме «Конец шамана» шаман изображался автором как плут, то в романе «Исчезнувшая девушка» теперь он жертва, более того - это борец за справедливость.

Финал романа автор завершает одой-восхвалением духовных богатств древней земли Тувы, которая сохранила шаманскую мифологию в первозданном виде.

\section{Заключение}

Модифицированные образы шаманов, развитые в литературном творчестве М. Б. Кенин-Лопсана, оказались весьма востребованными. Шаманизм как религия, как психология, как образ жизни все больше привлекает внимание современных людей, особенно ученых, не только как реликт для изучения традиционной культуры народов, но и как путь познания человека и мира.

Многогранность деятельности М. Б. Кенин-Лопсана позволяет рассматривать его и как исследователя шаманизма - ученого, и как шамана-практика, и как хранителя шаманских традиций, и как художника, творчески осмысляющего судьбы тувинского шаманизма.

Среди музейных проектов М. Б. Кенин-Лопсана, а он работал более 50 лет в Тувинском краеведческом музее, затем - Национальном музее им. Алдан-Маадыр Республики Тыва, основное место занимает коллекция шаманских атрибутов, которую он собирал с 1966 г. и впервые представил на выставке в 1993 г. И это закономерно, так как она создавалась на основе его научных трудов и художественных произведений о тувинском шаманизме. Архетипические фольклорно-мифологические и литературные образы шаманов, в том числе собирательный образ шаманки Хандыжап; образы главных помощниковидолов медведя и волка в этой коллекции занимают центральное место. Об этом свидетельствуют музейные экспозиции с высокохудожественными фотоиллюстрациями Ю. А. Косарькова и мастерски исполненными декоративными композициями В. Н. Елизарова. 
В 1990-2000-е годы комплексные музейные проекты М. Б. Кенин-Лопсана о шаманизме - выставки, вернисажи, лекции - вызвали большой интерес не только у самих носителей тувинской культуры, но и у туристов, путешественников, ученых. Эти годы были ознаменованы непосредственным выходом М. Б. Кенин-Лопсана на международный научный уровень. Он побывал по приглашению с лекциями и докладами во многих странах Европы - в Австрии (1995, 2002 гг.); Швейцарии, в Этнографическом музее г. Антверпен (1996 г.); Бельгии (1998 г.), Германии (1999, 2000 гг.); Италии (2002 г.), (США (1998 г.).

Собственно шаманские практики М. Б. Кенин-Лопсана известны в самой Туве и далеко за ее пределами. В течение нескольких десятилетий он оказывал помощь всем страждущим. Нескончаемый поток посетителей из кожунов, сумонов и городов Тувы - шаманисты и буддисты, учителя и научные сотрудники, писатели и художники, приезжие и путешественники - все шли к нему за помощью, консультацией, спасительным советом. Не зря народ назвал его «знатоком» тувинской души (Самдан, 2001). Его авторитет также сыграл большую роль в создании им централизованной сети шаманских объединений Тувы.

\section{СПИСОК ЛИТЕРАТУРЫ}

Бахтин, М. М. (1988) Эпос и роман (о методологии исследования романа) // Введение в литературоведение. Хрестоматия: учеб. пособие для филол. спец. вузов / сост.: П. А. Николаев и др., под ред. П. А. Николаева. 2-е изд. испр. и доп. М. : Высшая школа. 418 с. С. 417-420.

Гаспаров, М. Л. (1987) Анафора // Литературный энциклопедический словарь / под общ. ред. В. М. Кожевникова, П. А. Николаева; редкол.: Л. Г. Андреев, Н. И. Балашов, А. Г. Бочаров и др. М. : Советская энциклопедия. 752 с. С. 24.

Гофман, А. Б. (2008) От какого наследия мы не отказываемся? // Традиции и инновации в постсоветской России: социологический анализ взаимодействия и динамики / под ред. А.Б. Гофмана. М.: РОССПЭН. 541, [2] с. С. 9-112.

Донгак, У. А. (2007) Мифологизм романа М. Кенин-Лопсана «Исчезнувшая девушка» // Художественное наследие национальных литератур XX века в общероссийском культурном пространстве: проблемы взаимодействия / отв. ред. В. Н. Иванов. Якутск : Изд-во ИГИ АН РС(Я). 408 с. С. 65-71.

Донгак, У.А. (2017) Мифологические образы тенгрианства в тувинской поэзии: поэтика художественной модальности // Тенгрианство и эпическое наследие народов Евразии: истоки и современность / отв. ред. Л. В. Федорова. Астана : ТОО Мастер По. 509 с. С. 147-152.

Дэвлет, М. А. (2009) Живое сокровище шаманизма (предисловие) // Кенин-Лопсан М. Б. Тувинские шаманы. М.: Ликтон. 328 с. С. 10-27.

Итс, Р. (1966) Стрелы немой скалы: этногр. повесть. М. : Мысль. 112 с.

Кенин-Лопсан, М. Б. (1972) Конец шамана // Кенин-Лопсан М. Б. Киноварь. Стихи и поэмы: пер. с тув. Ю. Разумовского. Кызыл : Тувинское книжное издательство. 182 с. С. 111-127.

Кенин-Лопсан, М. Б. (1975) Чогаалдар чыындызы: шүлүктер, шүлүглелдер, проза чогаалдары [Избранное: стихи, поэмы, прозаические произведения] : в 2-х томах. Кызыл : Тувинское книжное издательство. Т. 1.424 с. (На тув. яз.).

Кенин-Лопсан, М. Б. (1977) К вопросу о категориях тувинских шаманов // Советская этнография. № 4. C. 92-95.

Кенин-Лопсан, М. Б. (1982) Сюжеты и поэтика тувинского шаманства: (опыт ист.-этногр. реконструкции) : автореф. дисс. ... канд. ист. наук. Л. 18 с.

Кенин-Лопсан, М. Б. (1987) Обрядовая практика и фольклор тувинского шаманства: конец XIX нач. XX в. Новосибирск : Наука. 164 с.

Кенин-Лопсан, М. Б. (1992) Тыва хамнарның алгыштары [Алгыши тувинских шаманов] / төөгү эртем. канд. М. Б. Кенин-Лопсан тург. Кызыл : Тыв. НҮЧ. 221 с. (На тув. яз.)

Кенин-Лопсан, М. Б. (1993) Магия тувинских шаманов. Кызыл : Новости Тувы. 159 с. (На тув., рус., англ. яз.).

Кенин-Лопсан, М. Б. (1995) Алгыши тувинских шаманов : Тыва хамнарның алгыштары. Кызыл : Новости Тувы. 572 с. 
Кенин-Лопсан, М. Б. (1996) Проблемы этнографического шаманизма: по материалам шаманского фольклора : автореф. дис.... д-ра ист. наук. СПб. 53 с.

Кенин-Лопсан, М. Б. (2000а) Буян-Бадыргы : роман-эссе : в 2-х кн. Кызыл : Новости Тувы. 544 с. (На тув. яз.).

Кенин-Лопсан М. (2000b) Читкен уруг [Исчезнувшая девушка]: Роман. Кызыл : Тываның ном үндүрер чери. 416 с. (На тув. яз.).

Кенин-Лопсан, М. Б. (2002) Мифы тувинских шаманов : Тыва хамнарның торулгалары. Кызыл : Новости Тувы. 544 с.

Кенин-Лопсан, М. Б. (2007) Алгыши тувинских шаманов : пер. авт. с тув. Якутск : Бичик. 206 с.

Кенин-Лопсан М. Б. (2010) Кара Дээрниң тыныжы - Дыхание Черного Неба: мифологич. наследие тувинского шаманства. Кызыл : Тыванын ном ундурер чери. 391 с.

Кенин-Лопсан М. Б. (2016) Судьба шаманки : роман. Абакан : ООО «Кооператив “Журналист”». 176 с.

Ламажаa, Ч. К. (2010) Архаизация, традиционализм и неотрадиционализм // Знание. Понимание. Умение. № 2. С. 88-92.

Ламажаa, Ч. К. (2013) Архаизация общества: Тувинский феномен / предисл. В. Г. Федотовой. М. : Книжный дом «Либроком». 272 с.

Мадюкова, С.А., Попков, Ю.В. (2010) Феномен социокультурного неотрадиционализма. СПб. : Алетейя. 132 с.

Мелетинский, Е. М. (2006) Поэтика мифа. 4-е изд., репр. М. : Восточная литература. 407 с.

Салчак, В. С. (2015) «Хамның буурааны» деп шүлүглелде хамнар дугайында бодалдарым [Взгляд на образы шаманов в поэме «Конец шамана»] // Чогаалдың судалы - алдын шыгжамырда [Пульс литературы - в золотом фонде]. Кызыл : Типография КЦО «Аныяк». 148 с. С. 34-39. (На тув. яз.).

Самдан, 3. Б. (2001) Живое сокровище шаманизма // Самдан 3.Б. Лики тувинской словесности. Часть III. Хранители ценностей: штрихи к портретам. Кызыл : Респ. типография. 78 с. С. 19-30.

Самдан, 3. Б. (2015) «Слово арата» - художественная летопись эпохи // Салчак Тока / Н. М. Моллеров, А. К. Канзай, Г. Ч.Ширшин и др. М. : Слово/Slovo. 544 с. С. 333-372.

Фаустов, А. А. (2008) Архетип // Поэтика: словарь актуальных терминов и понятий / гл. научн. ред. Н. Д. Тамарченко. М. : Издательство Кулажной ; Intrada. 358 с. С. 24.

Харунова, М. М.-Б. (2010) Проблемы возрождения национальной культуры в Туве в постсоветский период [Электронный ресурс] // Новые исследования Тувы. № 2. URL: https://nit.tuva.asia/nit/article/ view/525 (дата обращения: 10.03.2019).

Дата поступления: 11.03.2019 2.

\section{REFERENCES}

Bakhtin, M. M. (1988) Epos i roman (o metodologii issledovaniia romana) [Epic and novel (on the methodology of studying the novel)]. In: Vvedenie $v$ literaturovedenie. Khrestomatiia [Introduction to literary studies. A Reader]. Handbook for textbook for Philological majors of Universities / comp. by P. A. Nikolaev et al., ed. by P. A. Nikolaev. 2nd ed. Moscow, Vysshaia shkola. 418 p. Pp. 417-420. (In Russ.).

Gasparov, M. L. (1987) Anafora. In: Literaturnyi entsiklopedicheskii slovar' [An encyclopedic dictionary of literature] / ed. by V. M. Kozhevnikov and P. A. Nikolaev; editorial-board: L. G. Andreev, N. I. Balashov, A. G. Bocharov et al. Moscow, Sovetskaia entsiklopediia. 752 p. P. 24. (In Russ.).

Gofman, A. B. (2008) Ot kakogo naslediia my ne otkazyvaemsia? [What legacy are we not giving up?]. In: Traditsii i innovatsii v postsovetskoi Rossii: sotsiologicheskii analiz vzaimodeistviia $i$ dinamiki [Traditions and innovations in Post-Soviet Russia: sociological analysis of interaction and dynamics] / ed. by A. B. Gofman. Moscow, ROSSPEN. 541, [2] p. Pp. 9-112. (In Russ.).

Dongak, U. A. (2007) Mifologizm romana M. Kenin-Lopsana «Ischeznuvshaia devushka» [Mythologism of the novel "The Girl Who Disappeared" by M. Kenin-Lopsan]. In: Khudozhestvennoe nasledie natsional'nykh literatur XX veka v obshcherossiiskom kul'turnom prostranstve: problemy vzaimodeistviia [The heritage of national literature of the 20th century in the all-Russian cultural space: Problems of interaction] / ed. by V. N. Ivanov. Iakutsk, IGI AN RS (Yakutia) Publ. 408 p. Pp. 65-71. (In Russ.). 
Dongak, U. A. (2017) Mifologicheskie obrazy tengrianstva v tuvinskoi poezii: poetika khudozhestvennoi modal'nosti [Mythological images of Tengrianism in Tuvan poetry: Poetics of artistic modality]. In: Tengrianstvo i epicheskoe nasledie narodov Evrazii: istoki i sovremennost' [Tengrianism and the epic heritage of the peoples of Eurasia: Origins and modernity] / ed. by L. V. Fedorova. Astana, TOO Master Po. 509 p. Pp. 147-152. (In Russ.).

Devlet, M. A. (2009) Zhivoe sokrovishche shamanizma (predislovie) [The living treasure of shamanism (preface)]. In: Kenin-Lopsan M. B. Tuvinskie shamany [Tuvan shamans]. Moscow, Likton. 328 p. Pp. 10-27. (In Russ.).

Its, R. (1966) Strely nemoi skaly [Arrows of silent rock: An ethnographic story]. Moscow, Mysl'. 112 p. (In Russ.).

Kenin-Lopsan, M. B. (1972) Konets shamana [The end of the shaman]. In: Kenin-Lopsan M. B. Kinovar'. Stikhi i poemy [Vermillion: Poems]: transl. from Tuv. by Iu. Razumovskii. Kyzyl, Tuvan book publishing house. 182 p. Pp. 111-127. (In Russ.).

Kenin-Lopsan, M. B. (1975) Chogaaldar chyyndyzy: shülükter, shülüglelder, proza chogaaldary [Favorites: verses, poems, prose works] : in 2 vol. Kyzyl, Tuvan book publishing house. Vol. 1. 424 p. (In Tuv.).

Kenin-Lopsan, M. B. (1977) K voprosu o kategoriiakh tuvinskikh shamanov [On the categories of Tuvan shamans]. Sovetskaia etnografiia, no. 4, pp. 92-95. (In Russ.).

Kenin-Lopsan, M. B. (1982) Siuzhety i poetika tuvinskogo shamanstva: (opyt ist.-etnogr. rekonstruktsii) [Plots and poetics of Tuvan shamanism: a historical and ethnographic reconstruction)]: Thesis of Diss.... Candidate of History. Leningrad. 18 p. (In Russ.).

Kenin-Lopsan, M. B. (1987) Obriadovaia praktika i fol'klor tuvinskogo shamanstva: konets XIX - nach. XX v. [Ritual practice and folklore of Tuvan shamanism: late 19th - early 20th century]. Novosibirsk, Nauka. 164 p. (In Russ.).

Kenin-Lopsan, M. B. (1992) Tyva khamnarnyng algyshtary [Algyshes of Tuvan shamans] / transl. from Tuv. by the author. Kyzyl, Tuvan book publishing house. 221 p. (In Tuv.).

Kenin-Lopsan, M. B. (1993) Magiia tuvinskikh shamanov [The magic of Tuvan shamans]. Kyzyl, Novosti Tuvy. 159 p. (In Tuv., Russ. and Engl.).

Kenin-Lopsan, M. B. (1995) Algyshi tuvinskikh shamanov : Tyva khamnarnyng algyshtary [Algyshes of the shamans of Tuva]. Kyzyl, Novosti Tuvy. 572 p. (In Tuv. and Russ.).

Kenin-Lopsan, M. B. (1996) Problemy etnograficheskogo shamanizma: po materialam shamanskogo fol'klora [Problems of ethnographic Shamanism: from the shaman folklore]: Thesis of Dis.... Doctor of History. St. Petersburg. 53 p. (In Russ.).

Kenin-Lopsan, M. B. (2000a) Buian-Badyrgy: an essay novel: in 2 vols. Kyzyl, Novosti Tuvy. 544 p. (In Tuv.).

Kenin-Lopsan M. (2000b) Chitken urug [The girl who disappeared]: a novel. Kyzyl, Tuvan book publishing house. 416 p. (In Tuv.).

Kenin-Lopsan, M. B. (2002) Mify tuvinskikh shamanov [The myths of Tuvan shamans]. Kyzyl, Novosti Tuvy. 544 p. (In Russ.).

Kenin-Lopsan, M. B. (2007) Algyshi tuvinskikh shamanov [Algyshes of Tuvan shamans]: transl. from Tuv. by the author. Iakutsk, Bichik. 206 p. (In Russ.).

Kenin-Lopsan M. B. (2010) Kara Deerning tynyzhy - Dykhanie Chernogo neba: mifologich. nasledie tuvinskogo shamanstva [The breath of black sky: the mythological heritage of Tuvan shamanism]. Kyzyl, Tuvan book publishing house. 391 p. (In Tuv.)

Kenin-Lopsan M. B. (2016) Sud'ba shamanki [The fate of a shamaness]: a novel. Abakan, OOO «Kooperativ "Zhurnalist”». 176 p. (In Russ.).

Lamazhaa, Ch. K. (2010) Arkhaizatsiia, traditsionalizm i neotraditsionalizm [Archaization, Traditionalism and Neotraditionalism]. Znanie. Ponimanie. Umenie, no. 2, pp. 88-92. (In Russ.).

Lamazhaa, Ch. K. (2013) Arkhaizatsiia obshchestva. Tuvinskii fenomen [Archaization of the society. Tuvan phenomenon]. Moscow, Knizhnyi dom «Librokom». 272 p. (In Russ.)

Madiukova, S. A. and Popkov, Iu. V. (2010) Fenomen sotsiokul'turnogo neotraditsionalizma [Phenomenon of the sociocultural neotraditionalism]. St. Peterburg, Aleteiia. 132 p. (In Russ.).

Meletinskii, E. M. (2006) Poetika mifa [The poetics of myth]. 4nd ed. Moscow, Vostochnaia literatura. 407 p. (In Russ.). 
Salchak, V. S. (2015) «Khamnyng buuraany» dep shülüglelde khamnar dugaiynda bodaldarym [A look at shamans in the poem "The End of the shaman"]. In: Chogaaldyng sudaly - aldyn shygzhamyrda [The pulse of literature lies in the Golden Fund]. Kyzyl, Tipografiia KTsO «Anyiak». 148 p. Pp. 34-39. (In Tuv.).

Samdan, Z. B. (2001) Zhivoe sokrovishche shamanizma [The living treasure of Shamanism]. In: Samdan Z. B. Liki tuvinskoi slovesnosti [Faces of Tuvan literature]. Vol. III. Khraniteli tsennostei: shtrikhi k portretam [Sketches for the portraits of the keepers of values:]. Kyzyl, Republican printing house. 78 p. Pp. 19-30. (In Russ.).

Samdan, Z. B. (2015) «Slovo arata» - khudozhestvennaia letopis' epokhi [“The Arat's Word” as an artistic chronicle of the era]. In: Salchak Toka / N. M. Mollerov, A. K. Kanzai, G. Ch. Shirshin et al. Moscow, Slovo/Slovo. 544 p. Pp. 333-372. (In Russ.).

Faustov, A. A. (2008) Arkhetip [The Archetype]. In: Poetika: slovar' aktual'nykh terminov i poniatii [Poetics: a dictionary of relevant terms and concepts] / editor-in-shief N. D. Tamarchenko. Moscow, Publishing by Kulazhnoi; Intrada. 358 p. P. 24. (In Russ.).

Kharunova, M. M.-B. (2010) Problemy vozrozhdeniia natsional'noi kul'tury v Tuve v postsovetskii period [Problems of reviving a national culture in Post-Soviet Tuva]. The New Research of Tuva, no. 2 [online] Available at: https://nit.tuva.asia/nit/article/view/525 (access date: 10.03.2019). (In Russ.).

Submission date: 11.03 .2019 . 